\title{
Comparative Cross-Country Analysis of Sustainable Development of Russian Economy
}

\author{
Vladimir Tsitlenok ${ }^{1}$, Irina Roshchina ${ }^{1, *}$, Ekaterina Lisovskaya ${ }^{2}$, Igor Krishtal $^{2}$, and Elena \\ Rozhanskaya $^{2}$ \\ ${ }^{1}$ Tomsk State University, Institute of Economics and management, 634050 Lenin Avenue, 36, Tomsk, \\ Russia \\ ${ }^{2}$ Plekhanov Russian University of Economics, 117997 Stremyanny lane 36, Moscow, Russia
}

\begin{abstract}
This article addresses the phenomena of sustainable development of national economies driven by global inconsistency between nature resource intensive material production and severely limited natural resources. As a result, there is an increasing need for transition to global environmentally sound production. The article tests out the hypothesis about the mixed revolutionary and evolutionary nature of the sustainable development of the Russian economy. This type of sustainable development implies considerable fluctuations of its level depending on the scale and intensity of innovation activities. The results of the factor research and comparative cross-country analysis of the integral stability of the Russian economy are presented. The article provides the rationale for using more differentiated factors to rate national economies by the level of their dynamic sustainability. Dynamic sustainability factors that were identified made it possible to rate Russia's economy among other national economies by the level of its sustainable development. The article suggests causes for the potential decrease in the sustainability of the Russian economy in the context of the deployment of the 'Industry 4.0' global production and technology platform. It also sets out conditions as well as measures to reduce the risks of considerably unbalancing functional systems of the Russian economy.
\end{abstract}

Keywords: cross-country analysis, sustainability, types of sustainable development, national economy, factors, Russia, 'Industry 4.0'.

\section{Introduction}

The demands of a geo-anthropic society in vital goods are met in accordance with its accumulated productive potential. It is based on the achieved level of scientific knowledge, professional skills and abilities as well as forms, types and modes of production, management and the culture of productive relations. According to the research made by the Sustainable Society Foundation, a non-government organization based in the Netherlands, the sustainability of 154 national economies rose by 4\% between 2006 and 2016. 2\% growth was achieved due to human potential, production capital accounted for another $3 \%$ growth and there was a $1 \%$ drop in sustainability due to environmental issues. [1]. The use of existing

\footnotetext{
*Corresponding author: riv58@yandex.ru
} 
industrial technologies will result in the irreversible degradation of the environment and the erosion of its self-sustaining mechanism, causing a large shortage of natural resources needed for production and a significant price rise for all kinds of goods by the end of the XXI century.

Today, the development of a national-state system is dualistic due to its evolutionary and revolutionary features. The prevalence of only one of them can lead to either evolutionary or revolutionary type of sustainable development. The irregularities in economic development stem from "explosive" short-term fluctuations at all levels and in all aspects (functional, structural, factor, organizational, subject-behavioral) of a national state economy. Methods used for the transition of a national economy to "Industry 4.0" platform will determine the type of sustainable development (evolutionary-revolutionary or revolutionary-evolutionary), which in its turn will dominate its dynamics (growth or decline). The formation of 'Industry 4.0 ' production and technology platform is most likely to affect the sustainability of Russia's national economy. Thus, it is vital to determine conditions and possible measures to minimize the risks of considerably unbalancing the functional systems of the Russian economy.

According to the calculations based on the data [2], the divergence from average annual GDP growth in the countries of Western Europe between 1870 and 2003 was 2.57\%. Between 1870 and 1913 it amounted to $0.46 \%$, between 1913 and 1950 - to $(-1 \%)$, between 1950 and 1973 - to $(+2.6 \%)$, between 1973 and 2003 - to $(-0,38 \%)$ respectively. In the same centuries-long period average annual GDP growth in the USA amounted to $3.41 \%$; the divergences being $+0.53 \%$ in $1870-1913,-0.53 \%$ in $1913-1950,+0.52 \%$ in $1950-1973$ and $-0.47 \%$ in 1973-2003. Between 1873 and 2003 former territories of the Russian Empire and the Soviet Union saw an average GDP growth of 2.37\%. In 1870-1913 the divergence amounted to $+0.37 \%$, in $1913-1950$ - to $-0.22 \%$, in $1950-1973$ - to $+2.47 \%$, in $1973-$ 2003 - to $-1.28 \%$. Between 1989 and 1998 GDP dropped by 44\%, in 1998-2008 it increased by $95 \%$, in 2008-2017 GDP growth did not exceed 3\% [3].

The development of Russia's economy could be objectively determined as irregular and unstable. From 1870 to 2020 Russia subsequently saw 4 politico-economic systems: feudalmonarchic, bourgeois-democratic, state-socialistic, bourgeois-oligocratic. Every change of its politico-economic system came with a huge loss of national wealth, a partial loss of population and GDP. Russia was an object and a subject of two world wars and one civil was. The process of deindustrialization, that has been underway for the last decade of the XX century, was accompanied by a considerable cut-back in production and a drop in living standards.

The dependence of Russia's economy on international commodity and capital markets that deepened during the first two decades of the XXI century, contributed to the decrease in its dynamic sustainability. The implementation of decisions made at the top government level in 2007-2018 will require such restructuring of its economy production structure that could lead to a further decrease in its dynamic sustainability in a mid-term period, thus making the minimization of negative implications one of the major objectives for 2021-2035.

The notion "sustainable development of a national economy" embraces a whole spectrum of processes, happening in it at different levels and in different respects. That is why it is necessary to clearly define the area of research and to choose a reference point for economy's sustainable development analysis. In this case the research is limited to the factor aspect and comparative cross-country analysis of integral sustainability of the Russian economy. Material production is the main factor, in which cognitive potential of a national laborer is materialized. However, it in itself becomes the main destructive factor against the environment. [4]. That is why Zhang, S., Zhu, D. suggest a change of standards for evaluation when looking for an answer to the question, whether the countries have moved towards sustainable development (SD) or not. These researchers state: «First, a new SD definition, i.e. 'Achieving higher and more equally distributed well-being levels within ecological 
limits', is proposed. Second, based on the definition and from a global perspective, four criteria are established to judge whether countries have moved towards SD» [5].

Technological transformation of industrial production that will give it environmental properties as well as reducing the dependence of society on destructive forces of nature, including provision of the 'virus' safety, are one of the present-day priorities. This particular need has led to such a phenomenon as 'Industry 4.0' production and technology platform.

The goal of this research is to make a comparative analysis of dynamic stability of the Russian economy under conditions of its transition to 'Industry 4.0' production and technology platform.

The main objectives of the study are:

i. To outline the main factors that determine dynamic stability of the national economy

ii. To determine Russia's ranking according to its level of dynamic stability in the global economy

iii. To determine the likely impact of the 'Industry 4.0 ' production and technology platform on the stability of the Russian economy

iv. To determine decisions of the actors of the Russian economy for maintaining the achieved level of dynamic stability

The object of this research is the phenomenon of sustainable development of the national economy and its factors. The subject of the study encompasses methods for ensuring sustainable development of the Russian economy in the context of the 'Industry 4.0' production and technology platform formation.

Self-organizing systems theory was used as the methodological basis for studying the phenomenon of dynamic stability of the national economy.

Among the many competing methods for calculating the levels of dynamic stability of the national economy as a whole and its individual parts, the methodology developed by the World Bank experts based on the national accounting matrix is especially fitting for the purposes of this research [6].

The main hypothesis of this study is based on the statement on revolutionaryevolutionary type of the sustainable development of the Russian economy development, which suggests a significant fluctuation in its level depending on the scale and intensity of innovative activity. During periods of growth of the scale and intensity of innovation, the level of dynamic stability temporarily decreases, which determines lower rates of economic development relative to countries with evolutionary-revolutionary type of sustainable development.

\section{Results and Discussion}

Most researches consider the determining factors and building institutions that could ensure growth of public well-being without environmental destruction to be the main goal of the concept of sustainable development of the national economies. Experts from the Organization for Economic Cooperation and Development believe that sustainable development concept is the guideline for moving the world economy toward integrity and balance; it is the process of overcoming resource scarcity, social conflict, poverty and unemployment [7].

The sustainable development of the national economy phenomenon at the present stage is driven by global inconsistency between nature resource intensive material production and severely limited natural resources. This creates and intensifies the need for transition from nature-destructive production processes to nature-saving production processes.

There is a significant number of research papers devoted to the problem of correlation between economic development and availability of natural resources. In many cases those 
researches reach contradictory conclusions. This is due to the changes in the conditions of social development and the need to search for different approaches for their study. According to Nankani, Sachs and Warner the abundance of natural resources negatively affects economic development of countries with low and medium income levels [8-10]. A lot of researches outline negative effects of industrial production on environment [11-12]. According to independent studies, Sachs and Warner, as well as Hajkowicz reached similar and interrelated conclusions: large export-oriented natural resources sector impedes development of other spheres (primarily manufacturing) and distorts labor market by increasing demand for relatively low-skilled workers and thus decreasing motivation for getting a better education [13-15]. At the same time the research of Little, A.W., Green, A. shows the role of education in 'successful globalization' and how this links with agendas for sustainable development on the example of Japan and the East Asian tiger economies particularly South Korea and Taiwan. China, India, Kenya and Sri Lanka serve as an example of a positive impact of effective educational policy on economic development [16].

Thanh Le, as well as Cuong Le Van believe that exhaustible resources do not mean the end for sustainable development of the national economy. When a rational economic structure is formed, large deposits of exhaustible resources can have a positive influence on economic development [17]. There are numerous examples of successfully developing economies with limited resources (Hongkong, Singapore, Switzerland) as well as large deposits (USA, Canada, Australia, Chile) that make it doubtful that the so called 'resource curse' (or 'Dutch Disease') is caused by abundance of natural resources.

Most recent researches outline institutional and demographic factors as determining factors of sustainable economic development. It is also important to touch upon the issue of the search for new national development planning as a means for addressing the problems of sustainable development of the national economies. «The number of countries with a national development plan has more than doubled, from about 62 in 2006 to 134 in 2018. More than 80 per cent of the global population now lives in a country with a national development plan» [18].

Researches on the influence of 'Industry 4.0' on the sustainable development of the national economies deal with both theoretical [19] and applied [20-21] fields of knowledge.

Analysis of the main concepts of sustainable development of the national economy makes it possible to make the following conclusions:

i. Existing concepts are valid for selected objects: companies, industries, regions, national economies, economic activities of geo-anthropic society. These are the links of the future integral concept of sustainable development of the national economy.

ii. The concepts of sustainable economic development establish a desire of the society for creation of such a system where its growing positive needs include the need for creation of a platform based on minimal consumption of natural resources and preservation of the natural environment.

iii. Evolutionary formation of the new global productive and technological platform implies targeted creation of the new and transformation of the old productive, social and economic, institutional structures, cultural relations that would decrease the dependence of the economy from the state of the environment.

Study of the process of sustainable development of the national economy in relation to determining its main factors shows the need to take into account such factors as institutional, cultural, ideological, behavioral as well as industrial, socio-economic, environmental.

To assess the level and trajectory of sustainable development of the national economy it is important to outline a group of core factors: Gross Domestic Product (Purchasing Power Parity); population; human development; standard of living; value of accumulated wealth; 
financial system development level; level of international solvency; state of the environment and its self-reproduction level; innovation levels; global economic competitiveness; defense capacity; population satisfaction rate.

The main problem for creation of an integrated system of factors of sustainable development of the national economy is to harmonize all factors quantitively. For each individual factor, all national economies can be ranked based on ascending or descending value of their basic quality. The sum of the rankings of a specific national economy can be considered as a relative level of its dynamic stability. The difference in the number of countries included in the sample by rating organizations does not reduce the degree of reliability of the results, because for each of the national economies, the sum of the rankings remains the same.

The initial criterion for ranking the studied countries is the value of the gross national product produced in a year at purchasing power parity prices. The calculations carried out for the first 79 countries, which in 2018 accounted for $94 \%$ of the world gross product and $83.9 \%$ of the population of the Earth are selectively presented in Table 1. The table was created by the authors of this article using the data of official and informal organizations compiling ratings for relevant factors of sustainable development of the national economy [22-32].

Table 1. 2018 sustainable development ranking. Human development.

\begin{tabular}{|c|c|c|c|c|c|c|c|c|c|c|c|c|c|c|}
\hline \multirow[b]{2}{*}{ 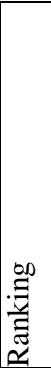 } & \multirow[b]{2}{*}{ Country } & \multicolumn{12}{|c|}{ Factors of sustainable development } & \multirow[b]{2}{*}{ 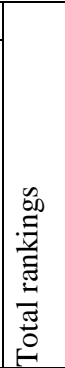 } \\
\hline & & 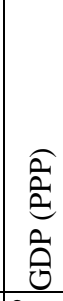 & 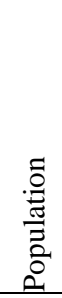 & 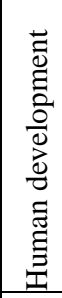 & 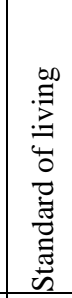 & 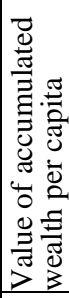 & 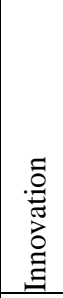 & 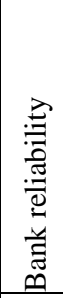 & 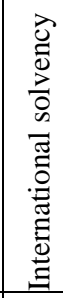 & 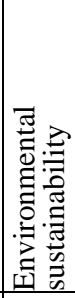 & 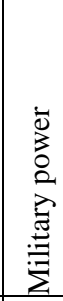 & 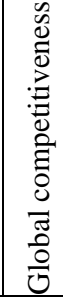 & 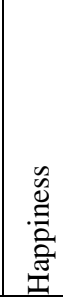 & \\
\hline 1 & USA & 2 & 3 & 13 & 11 & 15 & 3 & 25 & 3 & 27 & 1 & 2 & 19 & 124 \\
\hline 2 & Sweden & 41 & 9 & 8 & 4 & 5 & 2 & 44 & 2 & 5 & 31 & 8 & 7 & 166 \\
\hline 3 & Canada & 17 & 39 & 12 & 3 & 12 & 17 & 6 & 2 & 25 & 21 & 14 & 9 & 177 \\
\hline 4 & Great Britain & 10 & 21 & 14 & 16 & 16 & 5 & 52 & 9 & 6 & 8 & 9 & 15 & 181 \\
\hline 5 & Australia & 20 & 54 & 3 & 7 & 4 & 22 & 5 & 1 & 21 & 19 & 16 & 11 & 183 \\
\hline 6 & France & 9 & 20 & 24 & 20 & 13 & 16 & 39 & 8 & 2 & 5 & 15 & 24 & 195 \\
\hline 7 & Switzerland & 36 & 100 & 2 & 2 & 3 & 1 & 8 & 1 & 1 & 31 & 6 & 6 & 197 \\
\hline 8 & Germany & 5 & 18 & 5 & 14 & 10 & 15 & 64 & 1 & 20 & 10 & 7 & 58 & 227 \\
\hline 9 & Japan & 4 & 11 & 19 & 21 & 20 & 15 & 33 & 23 & 20 & 6 & 6 & 58 & 236 \\
\hline 10 & Netherlands & 26 & 68 & 10 & 9 & 11 & 4 & 18 & 1 & 18 & 35 & 4 & 35 & 239 \\
\hline 11 & Taiwan & 22 & 56 & 5 & 22 & 15 & 7 & 14 & 17 & 23 & 22 & 12 & 25 & 240 \\
\hline 14 & Norway & 53 & 117 & 1 & 1 & 1 & 19 & 10 & 2 & 14 & 36 & 13 & 3 & 270 \\
\hline 15 & South Korea & 14 & 28 & 23 & 26 & 22 & 11 & 64 & 14 & 60 & 7 & 13 & 54 & 336 \\
\hline 19 & Israel & 51 & 98 & 22 & 41 & 16 & 10 & 13 & 19 & 19 & 17 & 20 & 13 & 339 \\
\hline 23 & Hongkong & 44 & 103 & 7 & 19 & 17 & 13 & 3 & 10 & 50 & 70 & 3 & 76 & 415 \\
\hline 29 & Saudi Arabia & 16 & 41 & 40 & 52 & 34 & 68 & 15 & 25 & 86 & 25 & 36 & 28 & 466 \\
\hline 30 & Russia & 6 & 9 & 49 & 63 & 40 & 46 & 115 & 45 & 52 & 2 & 43 & 68 & 538 \\
\hline 31 & China & 1 & 1 & 86 & 53 & 58 & 14 & 95 & 20 & 120 & 3 & 28 & 93 & 572 \\
\hline 47 & Kuwait & 58 & 126 & 56 & 33 & 31 & 60 & 63 & 12 & 61 & 88 & 41 & 45 & 674 \\
\hline 70 & India & 3 & 2 & 130 & 108 & 101 & 52 & 89 & 43 & 177 & 4 & 68 & 140 & 917 \\
\hline 77 & Kenia & 75 & 27 & 142 & 118 & 108 & 77 & 99 & 67 & 130 & 86 & 95 & 121 & 1045 \\
\hline $\begin{array}{l}\text { Nur } \\
\text { in tl }\end{array}$ & $\begin{array}{l}\text { ber of countries } \\
\text { rating }\end{array}$ & 208 & 233 & 189 & 151 & 150 & 129 & 141 & 154 & 180 & 133 & 141 & 157 & \\
\hline
\end{tabular}


Thus, the highest level of sustainable development of the national economy was achieved in the USA, Sweden, Canada, Great Britain, Australia, France, Switzerland, Germany, Japan, and the Netherlands.

Russia ranked 30th in 2018, whereas China ranked 31st. Russia's highest level of dynamic stability is attributed to its defense capabilities (ranked 2nd) and gross domestic product (ranked 6th). The lowest relative stability is attributed to banking system (ranked 115th). Russia also ranked 63rd in standard of living and 68th in population happiness level.

Transition to the 'Industry 4.0' production and technology platform implies a significant increase in the contribution of knowledge-intensive sphere to the results of the high-tech industry by transforming scientific knowledge into knowledge-intensive goods. However, there are currently no comprehensive evaluation criteria to assess the level of knowledgeintensity of the 'Industry 4.0' production and technology platform. The modern-day Russian economy is characterized by the following peculiarities: a tendency toward a decrease or insignificant increase in the indicators of knowledge-intensity (the share of high-tech goods in GDP and the share of R\&D expenses); low share of enterprises that systematically create and market innovative products; decreasing number of researchers, especially in the industrial sphere.

\section{Conclusion}

One of the main reasons for the lower dynamic stability of the Russian economy is its continued specialization on primary energy commodities, other resources: timber, minerals and low research intensity goods: primary metals and agricultural produce.

Systematic innovation-based development of the Russian production implies the existence of a common relatively autonomous manufacturing resources market with knowledge-intensive engineering based on the predominance of national industrial and financial capital at its core. The share of machinery and equipment in the Russian commodity exports does not exceed $7 \%$, while their share in imports is more than 50\%.

Russian economy still has the status of a recipient of foreign knowledge-intensive technologies, industrial and consumer goods and foreign investments made mostly into resource-based industry, food industry, spheres of retail trade and finance. The project for the creation of a national knowledge-intensive engineering has stuck in a vicious circle. Foreign investments cannot be used a method for solving this problem. On the contrary, it could lead to liquidation, conversion or establishment of foreign management over Russian knowledge-intensive engineering companies. As the result, under conditions of the world financial or political crisis it could lead to a significant capital outflow.

It will be extremely difficult to achieve the projected target state of the Russian economy (reaching the level of a leading world power of the 21 st century) without a transition to internal (national) sources of development. The following long-term trends in global scientific and technological development should serve as guidelines for the priority distribution of production and financial resources for entities managing the national economy and private entrepreneurship:

i. transition to micro- and nanotechnologies: intensive development of technologies for production and application of materials with necessary parameters, transition to 3-D printing technologies;

ii. development of optoelectronic information technology for powerful supercomputers used in artificial intelligence systems;

iii. integration of certain types of technological processes into a single nanobio-info-cognitive system (NBICS).

So far, Russia's share in these processes does not exceed $0.2-0.3 \%$. Its share in the world market of high-tech goods in the next 10-20 years will not exceed several percent. 
Direct dependence of the national currency on dollar revenue from international commodities market and dollar exchange rate is one of the main factors for destabilizing of the Russian economy. During the period of ruble devaluation (1995-2019) the value of the ruble against the dollar decreased by 14 times.

By 2020 several persistent negative processes have formed that characterize Russian economy as a passive subject of a forming international sustainable economy, namely:

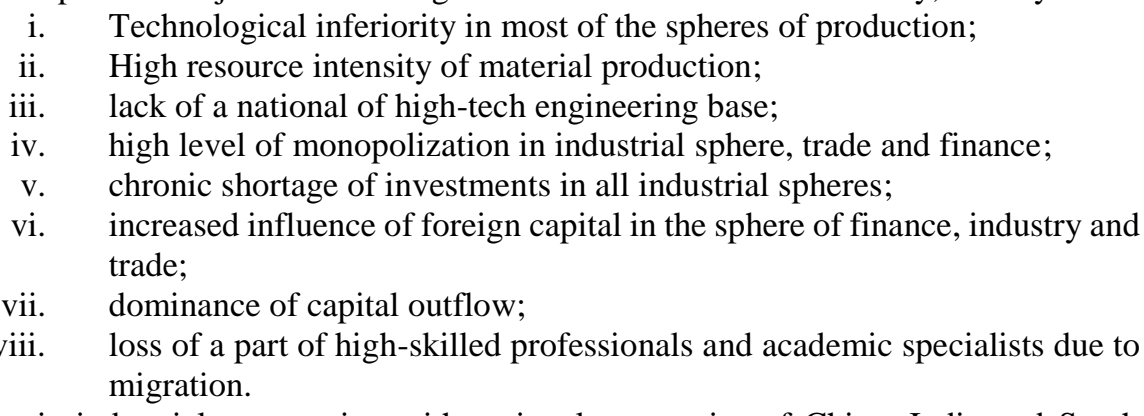

Systematic industrial cooperation with national economies of China, India and South Korea and other national-state economies ready for constructive cooperation is necessary for creation of a national scientific and technological platform 'Industry 4.0 - Russia' under conditions of decreasing general economic stability.

Minimizing the effect of a temporary decrease in the stability of Russian economy will become, in the medium-term perspective, a prerequisite for its transition to sustainable development beyond 2030.

\section{References}

1. SSF, Sustainable Society Index. Main Results (2016). http://www.ssfindex.com

2. A. Maddison, Contours of the World Economy 1-2030 AD. Essays in Macro-Economic History, M.: Gaidar Inst. Publ. H. (2012).

3. UNDP, Report on Human Development in the Russian Federation 2017. UN and Russia Sustainable Development Goals, Moscow: ACGRF(2017).

4. C. Bai, P. Dallasega, G. Orzes, J. Sarkis, Industry 4.0 Technologies Assessment: A Sustainability Perspective, Int. J. of Prod. Ec., 229(2020). https://www.sciencedirect.com/science/article/pii/S0925527320301559?via\%3Dihub

5. S. Zhang, D. Zhu, Have Countries Moved Towards Sustainable Development or Not? Definition, Criteria, Indicators and Empirical Analysis, J. of Cl. Prod., 267(2020). https://www.sciencedirect.com/science/article/abs/pii/S0959652620319764?via\%3Dih $\underline{\mathrm{ub}}$

6. G-M. Lange, Q. Wodon, K. Carey, The Changing Wealth of Nations 2018: Building a Sustainable Future. Washington, DC: World Bank (2018).

7. T. Strange, A. Bayley, Sustainable Development: Linking Economy, Society, Environment, OECD Insights, Paris: OECD Publishing (2008).

8. G. Nankani, Development Problems of Mineral-exporting Countries, World Bank Staff Working Paper, $\quad$ No. $354 \quad$ (1979). http://documents.worldbank.org/curated/en/777281468741386714/pdf/multi0page.pdf

9. J.D. Sachs, A.M. Warner, Sources of Slow Growth in African Economies, J. of Afr. Ec., 6(3): 335-376(1997). https://academic.oup.com/jae/article/6/3/335/993260

10. J.D. Sachs, A.M. Warner. Natural Resources and Economic Development: the Curse of Natural Resources, European Economic Review, 45(4-6): 827-838(2001). https://www.sciencedirect.com/science/article/abs/pii/S0014292101001258?via\%3Dih $\underline{\mathrm{ub}}$ 
11. K. Zaman, A. Abdullah, A. Khan, et al., Dynamic Linkages Among Energy Consumption, Environment, Health and Wealth in BRICS Countries: Green Growth Key to Sustainable Development, Ren. and Sust. En. Rev., 56: 1263-1271(2016). https://www.sciencedirect.com/science/article/abs/pii/S1364032115013933?via\%3Dih $\underline{\mathrm{ub}}$

12. J. Li, and B. Lin, The Sustainability of Remarkable Growth in Emerging Economies, Res., Conserv. and Rec., 145: 349-358(2019). https://www.sciencedirect.com/science/article/abs/pii/S0921344919300382?via\%3Dih $\underline{\mathrm{ub}}$

13. J.D. Sachs, A.M. Warner, Natural resources Abundance and Economic Growth, Cambridge: Harvard Institute of International Development (Development Discussion Paper № 517) (1995). https://www.nber.org/papers/w5398.pdf

14. J.D. Sachs, A.M. Warner, Natural Resources and Economic Development: the Curse of Natural Resources, Eur. Ec. Rev., 45(4-6): 827-838 (2001). https://www.sciencedirect.com/science/article/abs/pii/S0014292101001258?via\%3Dih $\underline{\mathrm{ub}}$

15. S. Hajkowicz, The Evolution of Australia's Natural Resource Management Programs: Towards Improved Targeting and Evaluation of Investments, Land Use Pol., 26(2): 471-478(2009).

16. A.W. Little, A. Green, Successful Globalisation, Education and Sustainable Development, Int. J. of Ed. Dev., 29(2): 166-174(2009).

17. T. Le, C. Le Van, Research and Development and Sustainable Growth over Alternative Types of Natural Resources, Ec. Model., 70: 224(2018). https://www.sciencedirect.com/science/article/abs/pii/S0264999317307368?via\%3Dih $\underline{\mathrm{ub}}$

18. A.O. Chimhowu, D. Hulme, L.T. Munro, The 'New' National Development Planning and Global Development Goals: Processes and Partnerships, W. Dev., 120: 7689(2019).

https://www.sciencedirect.com/science/article/pii/S0305750X19300713?via\%3Dihub

19. R.F. Gary, M. Fink, O. Belousova, Y. Marinakis, R. Tierney, S.T. Walsh, An Introduction to the Field of Abundant Economic Thought, Technological Forecasting and Social Change, 155(2020). https://www.sciencedirect.com/science/article/abs/pii/S0040162519319596?via\%3Dih $\underline{\mathrm{ub}}$

20. R. Strohmaier, M. Schuetz, S. Vannuccini, A Systemic Perspective on Socioeconomic Transformation in the Digital Age, J. of Ind. and Bus. Ec., 46: 361-378(2019). https://link.springer.com/article/10.1007/s40812-019-00124-y

21. L. Koh, G. Orzes, F. Jia, The Fourth Industrial Revolution (Industry 4.0): Technologies Disruption on Operations and Supply Chain Management, Int. J. of Op. \& Pro. Man., 39(6/7/8):

817-828(2019). https://www.emerald.com/insight/content/doi/10.1108/IJOPM-08-2019-788/full/html

22. Countries' Ranking by GDP (PPP) (2018). [in Russian]. https://nonews.co/directory/lists/countries/gdp-ppp

23. The population of the countries in the World to 2018. (2018). [in Russian]. https://infotables.ru/strany-i-goroda/17-tablitsa-chislennost-naseleniya-stran-mira

24. UNDP., Human Development Report $2019 . \quad$ (2019). http://hdr.undp.org/sites/default/files/hdr2019.pdf

25. Countries' Ranking by standard of living (2019). [in Russian]. https://tyulyagin.ru/ratings/rejting-stran-mira-po-urovnyu-zhizni.html

26. WIPO. The Global Innovation Index 2018: Energizing the World with Innovation (2018). https://www.wipo.int/edocs/pubdocs/en/wipo_pub_gii_2018.pdf 
27. Countries' Rating by the level of Bank reliability (2019). [in Russian]. https://nonews.co/directory/lists/countries/soundness-banks

28. Countries' Credit rating-list 2018. (2018). [in Russian]. https://ru.tradingeconomics.com/country-list/rating

29. Z.A. Wendling, J.W. Emerson, D.C. Esty, M.A. Levy, A. de Sherbinin et al. 2018 Environmental Performance Index. New Haven, CT: Yale Center for Environmental Law \& Policy. (2018). https://epi.yale.edu/

30. Countries' Global Firepower Rating (2019). [in Russian]. https://nonews.co/directory/lists/countries/global-firepower

31. WEF., The Global Competitiveness Report 2018. (2018). http://www3.weforum.org/docs/GCR2018/05FullReport/TheGlobalCompetitivenessR eport2018.pdf

32. J. Helliwell, R. Layard, J. Sachs, World Happiness Report 2019, New York: Sustainable Development Solutions Network. (2019). https://worldhappiness.report/ed/2019/\#read 